\title{
Comparison of the composition of wastewater from fruit and vegetables as well as dairy industry
}

\author{
Monika Puchlik ${ }^{1, *}$, and Joanna Struk-Sokołowska ${ }^{1}$ \\ ${ }^{1}$ Bialystok Technical University, Department of Technology in Engineering and Environmental \\ Protection, 45E Wiejska Street, 15-351, Poland
}

\begin{abstract}
The aim of the study was to compare the composition of wastewater from the facility producing fruit and vegetable juices and dairy processing plant in Podlasie province. Their composition is also influenced by processes of washing and disinfecting of production lines. The washing process moves solid, colloidal, and dissolved impurities to the wastewater, depending on the type of raw material processed and the technological process used. At the same time, cleaning and disinfecting components at the amounts difficult to determine, penetrate the wastewater. The seasonal oscillations in the quantity and quality of sewage composition originating from fruit-vegetable and dairy processing became a problem for many conventional wastewater treatment plants, to where they are discharged. Based on the survey, it was found that wastewater from the fruit and vegetable industry as well as dairy industry contained large amounts of organic matter expressed in $\mathrm{BOD}_{5}$ (fruits and vegetables processing from 860 to $3200 \mathrm{mg} \mathrm{O}_{2} / \mathrm{dm}^{3}$, dairy from 1410 to $3850 \mathrm{mgO}_{2} / \mathrm{dm}^{3}$ ) and COD (fruits and vegetables processing from 919 to $3700 \mathrm{mgO}_{2} / \mathrm{dm}^{3}$, dairy from 1680 to $5420 \mathrm{mgO}_{2} / \mathrm{dm}^{3}$ ). Significant differences were found in concentrations of nitrogen and phosphorus in compared raw wastewater.
\end{abstract}

\section{Introduction}

Food industry companies with the specifics of individual branches can be a source of many threats for all elements of the environment - soil, water, air, plants, animals, and humans. The food industry is part of the national economy department, which is engaged in the acquisition and processing of natural resources, and is one of the links in the food economy composed of many members closely related to one another [1]. It includes fruit and vegetable sector as well as dairy facilities producing a wide range of products, which occupy a central place in the food economy. Its aim is to satisfy people's basic needs, which are determined by the needs of a consumer and the needs and opportunities, especially in agriculture. Their common feature is the strong differentiation: there can be both preprocessing of agricultural products, and obtaining products with high degree of processing. The chemical composition of wastewater is very diverse, in its deposit mass consists of

\footnotetext{
* Corresponding author: m.puchlik@pb.edu.pl
} 
organic and inorganic compounds. The aim of the paper is to compare the composition of the raw sewage from dairy as well as fruit and vegetable industry. It was observed that the seasonal variations in quality of wastewater from the food industry have become a problem for many conventional sewage treatment plants, where they are discharged.

\section{Characteristics of raw sewage from the fruit and vegetable as well as dairy industry}

Fruit and vegetable production is characterized by seasonal campaigns, that fall mainly from June to October [2,3]. Activities in the processing and preservation of fruits and vegetables was shown by $88 \%$ of entities, while the remaining $12 \%$ was the production of juices and beverages [4]. Due to the nature and variety of processed raw material, wastewater from fruit and vegetable industry are difficult to characterize [5]. Most wastewater is produced in the first stage of manufacture. Wastewater generated from washing the fruits and vegetables are typically used once. In industry, water consumed in the first stage is preliminarily purified on a sieve and discharged to drain after washing the whole lot of fruits and vegetables, and then replaced with new water portions. In opinion by Nawirska [5], wastewater from fruit and vegetables plants are characterized by a high content of carbohydrates and minerals as well as variable composition depending on the raw material processed or time of the year [5]. Their composition is also affected by the processes of cleaning and disinfection of production lines. The washing process moves solid, colloidal and dissolved contamination to the wastewater depending on the type of raw material processed as well as on the process used. At the same time the sewage receives difficult to determine amounts of various components of detergents and disinfectants. Depending on wastewater generation place, following can be distinguished: raw material washing, cleaning, peeling, blanching, cooling (water after cooling), filling. The composition and amount of wastewater also depend on: the type, quality, settings, and size of dishwashers, type and origin of the raw material $[6,7]$. Wastewater generated during production of fruit concentrates are characterized by a $\mathrm{pH}$ values at the range from 5.8 to 9.4 and the COD value from 1030 up to $5630 \mathrm{mgO}_{2} / \mathrm{dm}^{3}$ [8]. In plants producing varied assortment, e.g. salads, pulps, or pickles, the $\mathrm{pH}$ can range from 4.9 to 7.7 , while COD value from 5260 to $270 \mathrm{mgO}_{2} / \mathrm{dm}^{3}$. These values depend on the production technology and currently processed assortment [8]. Wastewater from the fruit and vegetable production is low in nitrogen and its main impurity is an organic matter. According to the literature, $\mathrm{BOD}_{5}$ value ranges from 500 to $5000 \mathrm{mgO}_{2} / \mathrm{dm}^{3}$, and during the intensive production, it even exceeds $5000 \mathrm{mgO}_{2} / \mathrm{dm}^{3}$ [2, 9-11]. These levels are much higher than in household sewage $[2,12,13]$. Composition of wastewater produced in dairy processing plants depends primarily on the production profile. Other factors influencing the load of wastewater are raw materials used, technological level of the facility, processes of cleaning and disinfection, and the amount of water used $[14,15]$. Dairy wastewater are characterized by high loads of $\mathrm{COD}$ and $\mathrm{BOD}_{5}$ (fats, sugars, proteins), great qualitative variability (production line washing stage) $[16,17,18,19]$. According to literature data, dairy waste from all production lines can be purified altogether [20]. Composition of wastewater produced in the dairy processing plants depends mainly on the type of production and seasonality. There has been nearly $20 \%$ increase in supplied material in relation to the annual average in the summer and decrease in winter. Other factors influencing the composition and load of wastewater are raw materials used, technological level of the plant, processes of cleaning and disinfection, and the amount of water consumed. The second type of wastewater produced in dairy facilities are non-production sewage, among others, sanitary, post-cooling, storm, which are usually combined with the production wastewater and purified together [19,23]. Among plants that process milk, following should be 
distinguished: milk receiving points, small dairy plants (producing pasteurized milk, sour cream, kefir, yogurt, cottage cheese), as well as medium and large dairies with extended or full production profile (additionally producing melted and long maturing cheese, butter, powdered milk, ice cream) [21]. Typical dairy plant in Poland discharges contaminations of an average $\mathrm{BOD}_{5}$ about $1167 \mathrm{mgO}_{2} / \mathrm{dm}^{3}$ and COD $2077 \mathrm{mgO}_{2} / \mathrm{dm}^{3}$ [22,23]. Among dairy processing facilities, there are also objects discharging over $5000 \mathrm{~m}^{3} / \mathrm{d}$ wastewater, in which $\mathrm{BOD}_{5}$ value reaches $6000 \mathrm{mgO}_{2} / \mathrm{dm}^{3}$, and COD $9000 \mathrm{mgO}_{2} / \mathrm{dm}^{3}[22,23]$. Literature data show that the $\mathrm{pH}$ of wastewater depends on the type of production in a plant, and ranges from 6.4 to 7.6 [13]. According to Dąbrowski, nitrogen and phosphorus concentrations in dairy wastewater mainly depends on the quantity of chemicals used during the cleaning of devices in dairy plants [24].

\section{Materials and Methods}

The study was conducted in the laboratories of the Department of Technology in Engineering and Environmental Protection. Samples of raw sewage were collected 4 times a month from May to July in 2016 from two facilities located in Podlasie province. Facility A - processing of fruit and vegetables, producing mainly juice of fruit and vegetable purée, as well as facility B - dairy, in which the main products were hard cheese, yogurt and cottage cheese. The collected samples of raw sewage were subject to determinations of the following items in accordance with the current methodology:

- $\mathrm{COD}_{\mathrm{Cr}}$ - dichromate method according to PN-74/C-04578.03;

- $\mathrm{BOD}_{5}-$ manometric method using Oxi-Top Standard system;

- $\mathrm{P}_{\text {tot }}$ - spectrophotometric method according to PN-EN ISO 6878:2006;

- $\mathrm{N}_{\text {tot }}$ - spectrophotometric method using UV-VIS Pharo 300 device;

- acidity - potentiometric method PN-EN ISO 10523:2012;

- total suspended solids - gravimetric method PN-EN 872:2007+Ap1:2007.

\section{Results}

Wastewater from the fruits and vegetables and dairy processing (Table 1) were characterized, in comparison to municipal wastewater from collecting sewage, by many times higher values of $\mathrm{BOD}_{5}$ and $\mathrm{COD}_{\mathrm{Cr}}$ and comparable levels of nitrogen and phosphorus. Figure 1 shows variable volume fraction of wastewater from the fruit and vegetable as well as dairy industry since May to July 2016. The smallest volume of wastewater at fruit and vegetable processing plant, amounting to $6322 \mathrm{~m}^{3}$, was recorded in May, while the largest in July $\left(16527 \mathrm{~m}^{3}\right)$. In dairy processing facility, the smallest volume of wastewater was recorded in May $-20091 \mathrm{~m}^{3}$, while the largest in July $-22800 \mathrm{~m}^{3}$. A significant increase in the volume of wastewater (more than 2 -fold) was observed during the summer season for the plant producing fruit and vegetable juices (Figure 1). This is due to seasonal work in this type of production plant. The scope of changes in $\mathrm{BOD}_{5}$ and COD values from May to July is presented in Table 1. Calculations show that the ratio of COD to $\mathrm{BOD}_{5}$ for raw sewage in analyzed facilities is less than 2, which indicates that the wastewater is easily biodegradable. Figure 2 shows the range of variation of the average monthly values of COD and $\mathrm{BOD}_{5}$ values in raw sewage in 2016 for the plant producing fruit and vegetable juices and other products as well as for dairy processing plant. The highest load of COD in raw sewage was reported in the dairy in July, amounting to $123000 \mathrm{~kg}$, while the lowest in May, $5809 \mathrm{~kg}$, for fruits and vegetables processing plant. The maximum monthly load for $\mathrm{BOD}_{5}$ in raw sewage was observed in July with a value of $88920 \mathrm{~kg}$ for dairy, whereas the lowest in May $5436 \mathrm{~kg}$ in the fruit and vegetable facility. 
Figure 3 shows the average monthly change in the load of total nitrogen and total phosphorus in raw sewage. The lowest value of the total nitrogen load was recorded for fruit and vegetable processing plant in May, $252 \mathrm{~kg}$, while the maximum of $991 \mathrm{~kg}$ in July. In the dairy facility, the lowest value of total nitrogen load was recorded in June $-1487 \mathrm{~kg}$ and the highest, $1983 \mathrm{~kg}$, in July. Given the load of total phosphorus, it increased from $59 \mathrm{~kg}$ in May to $264 \mathrm{~kg}$ in July in fruit and vegetable processing plant. In the dairy, the lowest value of total phosphorus load was observed in May $-252 \mathrm{~kg}$ and the highest in July $-501 \mathrm{~kg}$. The highest monthly average value of COD concentrations for processing plants were recorded in July: dairy - $5420 \mathrm{mg} \mathrm{O} / \mathrm{O}_{2}^{3}$, fruit and vegetable processing plant - $3700 \mathrm{mg} \mathrm{O}_{2} / \mathrm{dm}^{3}$; the lowest in May, $1680 \mathrm{mg} \mathrm{O} / \mathrm{dm}^{3}$ in the dairy, and $919 \mathrm{mg} \mathrm{O} / \mathrm{Om}^{3}$ for processing fruits and vegetables (Table 1). The highest average monthly amount of organic matter expressed in $\mathrm{BOD}_{5}$ in raw wastewater was $3200 \mathrm{mg} \mathrm{O} / \mathrm{dm}^{3}$ in July in fruit and vegetable processing facility, while $3900 \mathrm{mg} \mathrm{O} \mathrm{O}_{2} / \mathrm{dm}^{3}$ in the dairy. The lowest concentration of total suspended solids in raw sewage was $200 \mathrm{mg} / \mathrm{dm}^{3}$ for dairy in May, while the highest was recorded in July with a value of $420 \mathrm{mg} / \mathrm{dm}^{3}$ for the processing of fruits and vegetables (Table 1). An analysis of monthly average concentrations of total nitrogen and total phosphorus in the raw wastewater from the fruit and vegetable as well as dairy processing, reveals that the highest value of total nitrogen, $87 \mathrm{mgN} / \mathrm{dm}^{3}$ was recorded in July for dairy plant, while the lowest value, $40.0 \mathrm{mgN} / \mathrm{dm}^{3}$, in May for juice production. The highest concentration of total phosphorus in raw sewage was $22.0 \mathrm{mg} \mathrm{P} / \mathrm{dm}^{3}$ in July in the dairy, and in May, more than 2 times lower amounting to $9.4 \mathrm{mg} \mathrm{P} / \mathrm{dm}^{3}$ in the plant processing fruits and vegetables. It has been observed that wastewater directly related to the production of food has a variable $\mathrm{pH}$ value from 4.3 up to 9.4 (Table 1).

Table 1. Average monthly values for raw sewage.

\begin{tabular}{|c|c|c|c|c|c|c|c|}
\hline \multirow{3}{*}{ Parameter } & \multirow{3}{*}{ Unit } & \multicolumn{6}{|c|}{ Raw wastewater } \\
\hline & & \multicolumn{3}{|c|}{$\begin{array}{c}\text { Fruits and vegetables } \\
\text { processing }\end{array}$} & \multicolumn{3}{|c|}{ Dairy } \\
\hline & & $\mathrm{V}$ & VI & VII & $\mathrm{V}$ & VI & VII \\
\hline BOD & $\mathrm{mgO}_{2} / \mathrm{dm}^{3}$ & 860 & 2200 & 3200 & 1220 & 2800 & 3900 \\
\hline COD & $\mathrm{mgO}_{2} / \mathrm{dm}^{3}$ & 919 & 3350 & 3700 & 1680 & 3300 & 5420 \\
\hline $\mathrm{N}_{\text {tot. }}$ & $\mathrm{mgN} / \mathrm{dm}^{3}$ & 40.0 & 48.0 & 60.0 & 76.0 & 69.0 & 87.0 \\
\hline $\mathrm{P}_{\text {tot. }}$ & $\mathrm{mgP} / \mathrm{dm}^{3}$ & 9.4 & 14.8 & 16.0 & 12.6 & 16.0 & 22.0 \\
\hline TSS & $\mathrm{mg} / \mathrm{dm}^{3}$ & 249 & 356 & 420 & 200 & 245 & 286 \\
\hline $\mathrm{pH}$ & - & $5.5-7.2$ & $4.3-7.1$ & $4.6-7.9$ & $6.1-9.3$ & $6.6-9.0$ & $6.8-9.4$ \\
\hline
\end{tabular}




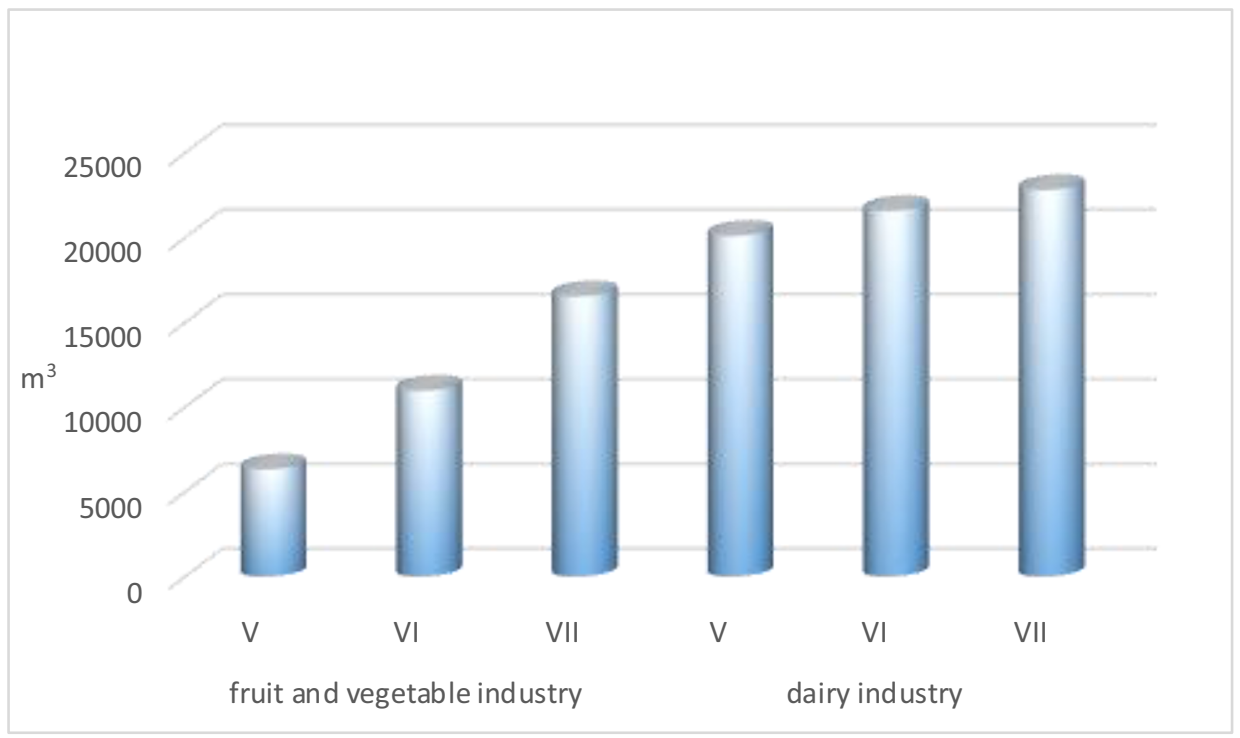

Fig. 1. The average monthly volume of raw sewage from the fruit and vegetable as well as dairy industry since May to July 2016.

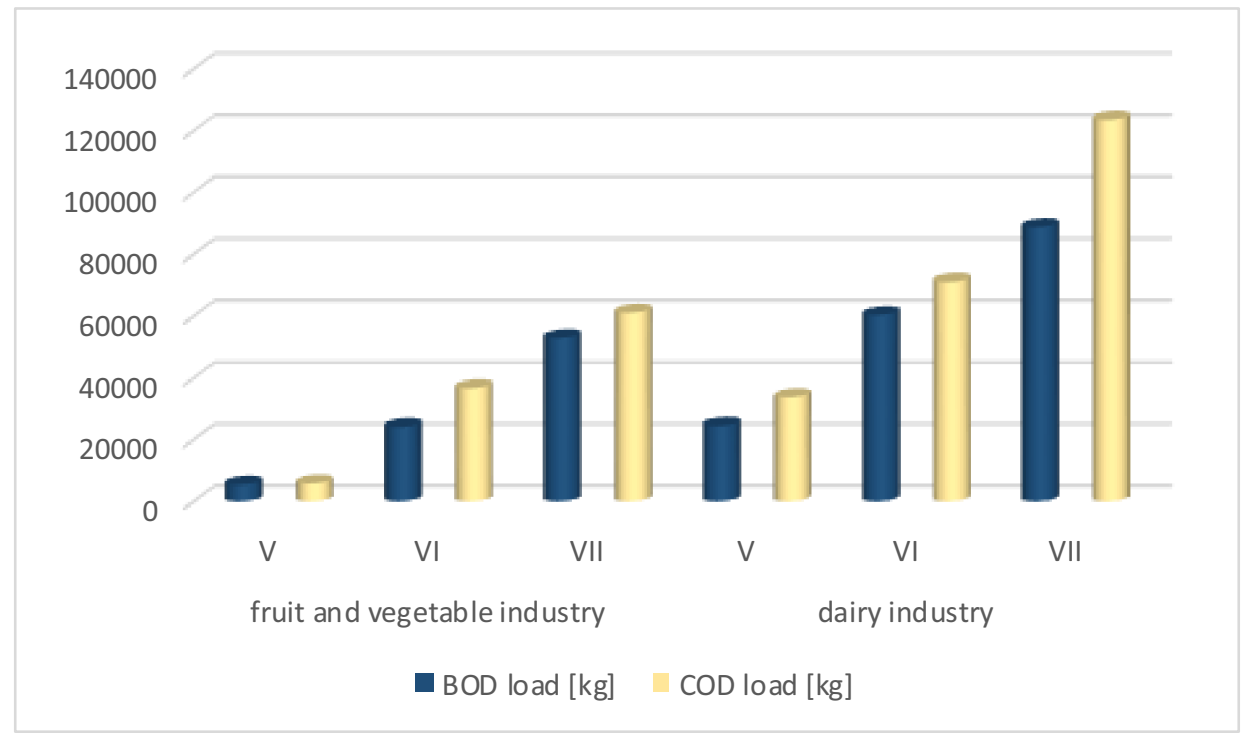

Fig. 2. The average monthly $\mathrm{COD}$ and $\mathrm{BOD}_{5}$ loads in raw sewage from the fruit and vegetable as well as dairy industry since May to July 2016. 


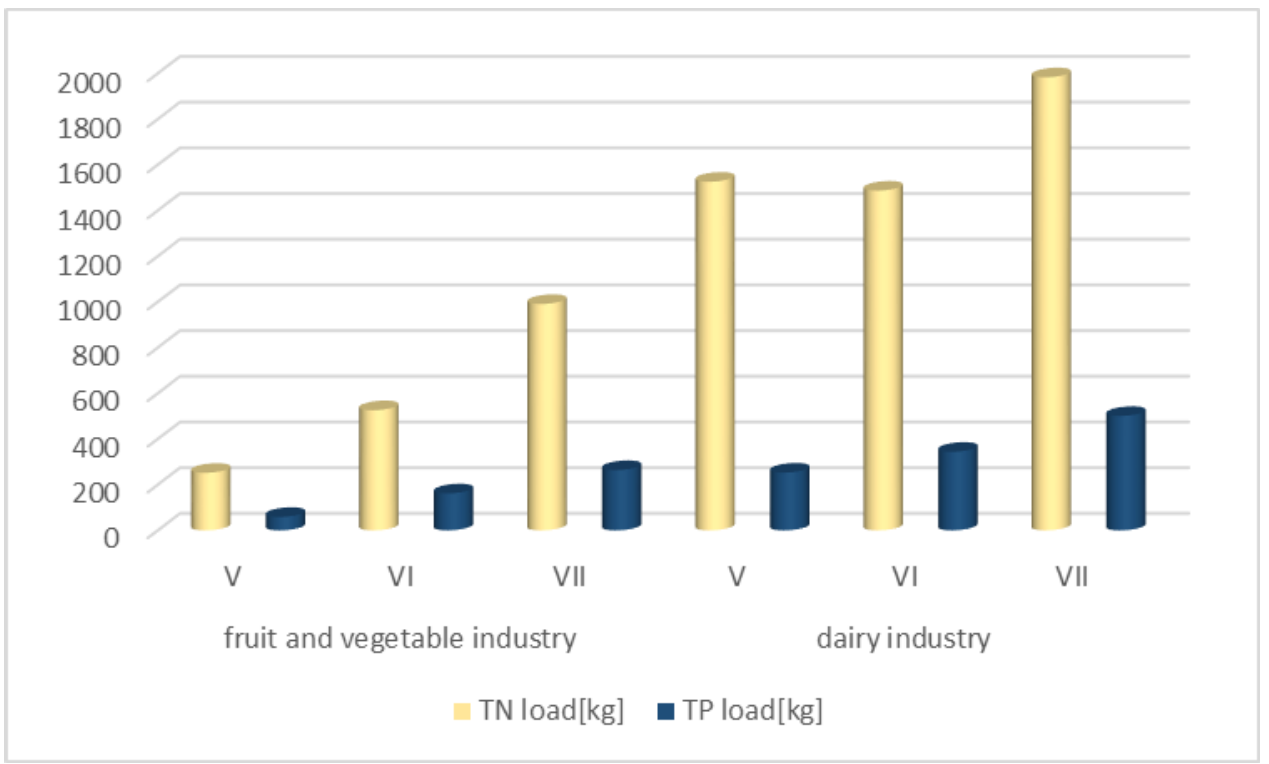

Fig. 3. The average monthly $\mathrm{N}_{\text {tot. }}$ and $\mathrm{P}_{\text {tot. }}$ loads in raw sewage from the fruit and vegetable as well as dairy industry since May to July 2016.

\section{Conclusions}

Analysis of determinations allow for the following statements:

1. In the analyzed facilities, the main contaminant was organic matter expressed in COD and $\mathrm{BOD}_{5}$.

2. The ratio of $\mathrm{COD}$ to $\mathrm{BOD}_{5}$ for raw wastewater is smaller than 2 , which indicates that this sewage is readily biodegradable.

3. There were small variations in the concentrations of total nitrogen and phosphorus resulting from the production profile and chemicals used for the cleaning of equipment in facilities.

4. Significant fluctuations in the quantity and quality of wastewater from the food industry during the production campaigns may represent a problem for many conventional sewage treatment plants, to which they are discharged.

The research has been carried out in the framework of project No. MB/WBiIŚ/13/2015 and financed from the funds for science MNiSW.

\section{References}

1. M. Puchlik, J. Struk-Sokołowska, E. Wołejko, U. Wydro, Problem oczyszczania ścieków $\mathrm{z}$ przemysłu spożywczego w małych i średnich przedsiębiorstwach, Interdyscyplinarne zagadnienia w inżynierii i ochronie środowiska, T7 (2016)

2. M. Soroko, Oczyszczanie ścieków z małych przetwórni owocowo-warzywnych w oczyszczalniach hydrofitowych, Woda Środowisko Obszary Wiejskie, T 3 (2003)

3. M. Soroko, Skuteczność oczyszczania ścieków $z$ małych ubojni i przetwórni owocowo-warzywnych w systemach hydrofitowych, PAN, Oddział w Krakowie 3, $1(2006)$ 
4. S. Kierczyńska, Produkcja warzyw i owoców oraz ich przetwórstwo w Polsce, Roczniki Seria, T X, 4 (2008)

5. A. Nawirska, Gospodarka wodno-ściekowa w przemyśle owocowo-warzywnym., Agro Przemysł 3/2007 (2007)

6. A. Nawirska, L. Szymański, Gospodarka wodno-ściekowa w zakładach przemysłu spożywczego, Wydawnictwo Akademii Rolniczej we Wrocławiu (2002)

7. M. Puchlik, Application of constructed wetlands for treatment of wastewater from fruit and vegetable industry, J. Ecol. Eng. - Vol. 17, 1 (2016)

8. D. Kopiec, Ścieki z zakładów spożywczych-doświadczenia z Miejskiej Oczyszczalni Ściekow w Błoniu, Przegląd Komunalny 2 (2007)

9. B. Koziorowski, Oczyszczanie ścieków przemysłowych. Warszawa: WTN (1980)

10. F. Meinck, H. Stoof, Kohlschutter, Ścieki Przemysłowe (1975)

11. B. Talik, B. Chudzik, Oczyszczanie ścieków z małych przetwórni owocowowarzywnych zlokalizowanych na wsi. IMUZ T 20, 3 (2000)

12. M. Puchlik, K. Ignatowicz, W. Dąbrowski ,Influence of bio-preparation on wastewater purification process in constructed wetlands, J. Ecol. Eng. - Vol. 16, 1 (2015)

13. B. Bartkiewicz, K. Umiejewska, Oczyszczanie ścieków przemysłowych, Wyd PWN (2010)

14. J. Struk-Sokołowska, Wpływ ścieków mleczarskich na frakcje ChZT ścieków komunalnych, IE 24 (2011)

15. M. Wojnicz, A. M. Anielak, Badania nad możliwością oczyszczania ścieków przemysłu mleczarskiego $\mathrm{w}$ systemie SBR z wykorzystaniem zeolitu naturalnego, Oczyszczanie ścieków i przeróbka osadów ściekowych, Oficyna Wyd. Uniwersytetu Zielonogórskiego, 2 (2008)

16. B. Buczak, Oczyszczanie ścieków mleczarskich z uwzględnieniem usuwania azotumity i rzeczywistość, III Konferencja Naukowo-Techniczna. Woda i ścieki w przemyśle spożywczym. Białystok (2010)

17. B. Demirel, O. Yenigun, T.T. Onay, Anaerobic treatment of dairy wastewater: a review. Proc. Biochem. 40 (2005)

18. E. Neczaj, M. Kacprzak, T. Kamizela, J. Lach, E. Okoniewska, Sequencing batch reactor system for the co-treatment of landfill leachate and dairy wastewater. Desalination, 222 (2008)

19. J. Struk-Sokołowska, K. Ignatowicz, Współoczyszczanie ścieków komunalnych i mleczarskich w oczyszczalniach typu SBR. Rocznik Ochrony Środowiska (Annual Set The Environment Protection), 15 (2013)

20. W. Janczukowicz, M. Zieliński, M. Dębowski, Biodegradability evaluation of dairy effluents originated in selected sections of dairy production. Biores. Techn., 99 (2008)

21. A. M. Anielak, Gospodarka wodno-ściekowa przemysłu mleczarskiego, Agro Przemysł 2 (2008)

22. J. Struk-Sokołowska, Wpływ ścieków mleczarskich na frakcje ChZT ścieków komunalnych, IE 24 (2011)

23. J. Struk-Sokołowska, Ocena efektywności pracy oczyszczalni ścieków

24. w Siemiatyczach, Interdyscyplinarne zagadnienia w inżynierii i ochronie środowiska, T 4 (2014)

25. W. Dąbrowski, Oczyszczanie odcieków z oczyszczalni mleczarskich w systemach hydrofitowych, Monografia (2014) 